\title{
Digital Commons
}

\section{Crossing the Digital Divide: Race, Writing, and Technology in the Classroom, by Barbara Jean Monroe}

Anita Foraker

Follow this and additional works at: https://digitalcommons.lmu.edu/ce

\section{Recommended Citation}

Foraker, A. (2007). Crossing the Digital Divide: Race, Writing, and Technology in the Classroom, by Barbara Jean Monroe. Journal of Catholic Education, 11 (2). http://dx.doi.org/10.15365/joce.1102152013

This Book Review is brought to you for free with open access by the School of Education at Digital Commons at Loyola Marymount University and Loyola Law School. It has been accepted for publication in Catholic Education: A Journal of Inquiry and Practice by the journal's editorial board and has been published on the web by an authorized administrator of Digital Commons at Loyola Marymount University and Loyola Law School. For more information about Digital Commons, please contact digitalcommons@lmu.edu. To contact the editorial board of Catholic Education: A Journal of Inquiry and Practice, please email CatholicEdJournal@lmu.edu. 


\title{
CROSSING THE DIGITAL DIVIDE: RACE, WRITING, AND TECHNOLOGY IN THE CLASSROOM
}

\author{
BARBARA JEAN MONROE \\ TEACHERS COLLEGE PRESS, 2004 \\ $\$ 23.95,176$ pages
}

Reviewed by Anita Foraker

Crossing the digital divide is inevitable in the education process. "The question is no longer if the Internet can be used to transform learning in new and powerful ways. The Commission has found that it can. The issue before us now is how to make good on the Internet's promise for learning" (p. 116). Monroe provides case studies of high-poverty secondary schools as they began using the Internet and offers an assessment of the literacy practices of some of the most underprivileged students. The author puts focus on several points: (a) the need to recognize that disparities exist among socioeconomic classes; (b) the differences in attitudes that people have toward technology; (c) the need for awareness of changing demographics; and (d) the necessity of instructional "technology as a tool to improve academic achievement" (p. 122).

Monroe begins with recognizing that disparities among groups do exist. One of the biggest disparities she found among the students were the resources available to them and their limited access in and out of school: "The network was down more often than it was up" (p. 116). Many school buildings in low socioeconomic areas had inadequate electrical wiring that prevented the computers from running simultaneously, printers from being networked, and district server problems. Additionally, schools were provided with little technical support. In some cases, teachers had limited access in their schools and were forced to stay with traditional classroom practices of basic-skills knowledge: "Many of the teaching gains were lost as the schools were either unable to keep up with the demand or unable to sustain computing resources or disallowed open access to teachers and students" (p. 120).

Monroe studied different attitudes toward technology and "polarized the issue as a matter of simply having, or not having, access to the Internet" ( $p$. 5). She found that some people simply did not want to be connected to the Internet. This distinguishes between people who are of lower socioeconom- 
ic class that do not have computers and those that have computers but do not want access to the Internet. Monroe makes the point that teachers "show administrators that IT can be used in transformative ways... and there is indeed a pressing need for Internet access" (p. 124) in improving their students' literacy. In Monroe's study, college students provided an online tutoring service for students in the different socioeconomic areas, pairing them randomly. The females outnumbered the males significantly: "Of the 27 pairs in the project, 18 were female tutor-female student, 6 were female tutor-male student, and 3 were male tutor-female student" (p. 49). Monroe discovered that female students were more involved in their writings to their tutors and had better keyboarding skills than the male students. They also wrote more expressive material to their tutors.

Overall, Monroe's study was informative and inspirational. Many schools questioned the importance of technology in the educational system and were hesitant to make the shift into the technology age but found that it "had transformed this school" (p. 115). One of the schools was originally the most isolated school in the area but after the study was the most computerliterate in the district:

Enrollment spiked an extra hundred students from 1995 to 1996 to an all-time high of 1,906. This spike was a direct result of the school's high profile and newfound reputation for computer access, according to the principal. And absenteeism decreased for the year of the project, according to teachers, because students wanted to work on computers. (p. 115)

On the other hand, one of the schools in the study did not fare as well. Teachers of lower socioeconomic schools are under more pressure to focus on the basic skills, and are often mandated to "teach to the test by administrators" (p. 121) so they revert back to traditional practices of teaching basicskills knowledge. These tests drive the curriculum as well as instructional priorities at many schools. Equality among the digital divide will always be an issue as long as power and poverty exist.

Teachers in high-poverty schools can act now by transforming their own classroom practices, even if school access is limited or even nil. In high-SES communities where schools are most likely to have access in labs and in the classroom, students do not want to use computers at school, preferring to use their own home computers. (p. 123)

Low-SES students are finding other alternative methods to getting connected to the Internet in order to become computer literate. "They're resourceful" (p. 123) says one of the teachers from the study. 
In this reviewer's opinion, technology has a major impact on a student's achievement and performance. Teachers need to educate the administration and parents on the importance of technology accessibility. Monroe discovered that students' writing improved and students became more literate through on-line discussions and written communications with their tutors. As a result, the author concludes that by using electronic environments, such as e-mail, we can help our students "break linguistic isolation" (p. 61) as they develop their own critical literacies. "Change is only skin-deep without technological and critical pedagogy to sustain it" (p. 116).

\title{
HURT: INSIDE THE WORLD OF TODAY'S TEENAGERS
}

\author{
CHAP CLARK
}

BAKER ACADEMIC, 2004

$\$ 16.99,240$ pages

Reviewed by Michael Motyl

What do parents, pastors, educators, and youth ministers all have in common? The answer is the desire to deeply understand the reasoning and behavior of the teenager. There has been much research about the behavioral patterns of today's teenagers in an effort to answer the question, "Why are teenagers the way they are?" Often, despite producing undeniable facts about what teenagers are doing, the research does not clearly explain to the reader why teenagers do what they do and think what they think. The educator, youth minister, parent, and pastor can find some solace in Clark's Hurt: Inside the World of Today's Teenagers. Clark contends that adolescence is fundamentally different today than it was in past decades. Hurt suggests that there are large numbers of teenagers that have been abandoned by adults and schools, and are not only at risk but are being deserted by well-intentioned adults. Clark provides knowledge and insight as to how to connect with teenagers who are alone and in pain. 